sellaisia tekijöitä ja rakenteita, jotka asettavat yksilöt eriarvoiseen asemaan koulutusmahdollisuuksien suhteen. Poliittisten päättäjien vastuulle jää viime kädessä se, miten tutkimustietoa aiheesta hyödynnetään. Suosittelen kirjaa kaikille korkeakoulutuksesta kiinnostuneille, mutta aivan erityisesti koulutuspoliittisille päättäjille.
HANNA NORI

$\mathrm{KT}$, yliopistotutkija

kasvatustieteiden laitos

Turun yliopisto

(iD) https://orcid.org/0000-0002-

6612-9830

\title{
LÄHTEET.
}

Heiskala, L., Erola, J. \& Kilpi-Jakonen, E. (2020).

Compensatory and multiplicative advantages:

Social origin, school performance, and stratified

higher education enrolment in Finland. European

Sociological Review, 1-15. DOI: https://doi.

org/10.1093/esr/jcaa046.

\section{Tutkimus vaatii vapautta}

Esa Väliverronen \& Kai Ekholm (toim.) (2020). Tieteen vapaus ja tutkijan sananvapaus. Vastapaino. 360 sivua.

VAIKKA TIETEEN vapaus ja tutkijan sananvapaus kytkeytyvätkin käytännössä usein toisiinsa, ne ansaitsevat kumpikin omat tarkastelunsa. Vapaus on tieteen elinehto. Se kuuluu tieteen olemukseen. Tiede syntyi ja pääsi kehittymään Euroopassa vasta, kun kirkko dogmeineen vapauden tukahduttajana menetti valtaansa.

Toki nykyäänkin esimerkiksi kansallisella tasolla tieteen vapautta rajoittavat ja uhkaavat niin poliittiset kuin taloudelliset tekijät. Tiedeyhteisö saa olla jatkuvasti varuillaan puolustaakseen tieteen vapautta, mikä näyttäytyy myös poliittisena kysymyksenä. Päätöksentekijöiden intohimot leimahtavat näkyville keskusteltaessa, mitä tutkimusta kannattaa rahoittaa ja mihin tarpeeseen tutkimusta tulisi tehdä.

Niin ajankohtaisia teemoja kuin hiukan historiaakin luotaava Tieteen vapaus ja tutkijan sananvapaus on kirjoitettu 17 tutkijan voimin, joista monet tunnetaan tieteen puolustajina ja huuhaan vastustajina julkisista puheenvuoroistaankin. Kirja koostuu 12 artikkelista, joista osa on empiirisiä tutkimuksia ja osa teoreettisia jäsentelyjä. Mukana on kaksi historiallista tarkastelua.

\section{KUKA PUOLUSTAISI VAPAUTTA?}

Tutkijan sananvapaus on ollut 2000-luvulla uhattuna erityisesti autoritaarisesti johdetuissa maissa. Kirjan toimittajat ovat koonneet johdantolukuun muutaman kuvauksen tutkijoiden vaienta-

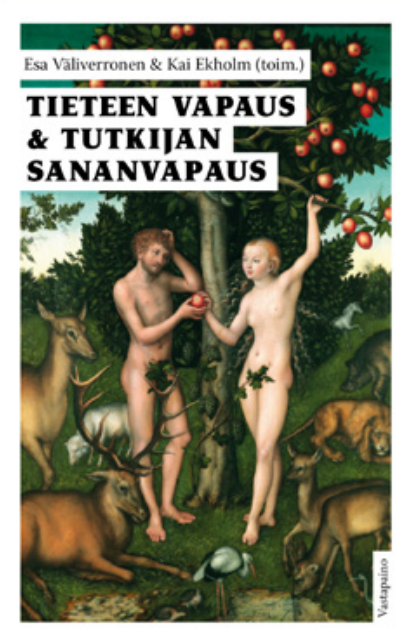

misesta ja tieteen sensuurista Yhdysvalloissa, Kiinassa, Tšekin tasavallassa ja Unkarissa. Kun tiede ja tieteenharjoittaminen ovat muuttuneet yhä enemmän projektiluonteiseksi, tutkijoiden on vaikeampi puolustaa tieteen vapautta.

On todennäköistä, että mitä epävarmempi tutkijan asema on, sitä helpompi häneen on vaikuttaa poliittisella tai taloudellisella ohjauksella. Tieteen vapauden 
puolustaminen edellyttää vapauden takaavia käytäntöjä ja mekanismeja mutta myös toimijoita. Niin ylevältä kuin tieteen vapaus kuulostaakin, se voi elävässä elämässä vaatia uhrautumista. Tutkijakin on lopulta vain elantonsa kanssa kamppaileva ja itseään hankaluuksilta suojeleva palkansaaja.

Vapaalla tieteellä on toki kannattajia, mutta tietynlaisissa oloissa vapauden uhkaajia vastaan nouseminen on vaikeaa.

\section{MONENSUUNTAINEN KONTROLLI}

Yksi kirjan artikkeleista onkin tutkimus siitä, miten ”tutkijat vaikenevat itsesuojeluvaiston perusteella”. Sen aineistona on tiedonjulkistamisen neuvottelukunnan vuonna 2017 keräämä kyselyaineisto, jossa tutkijat kertovat kokemuksistaan tieteen vapauden ja sananvapauden rajoittamisesta. Osa rajoittavasta kontrollista suuntautuu "ylhäältä alas", osa puolestaan "alhaalta ylös". Osa kontrollista on horisontaalista.

Vaientamiskokemukset jakautuvat neljään pääluokkaan: 1) poliittiseen ja talouden ohjaukseen, 2) organisaation ohjaukseen, 3 ) tutkijoiden keskinäiseen kontrolliin ja 4) yksityishenkilöiden tai yhteisöjen tutkijoihin kohdentamiin vaientamispyrkimyksiin.
Kaikista näistä ohjauksen ja kontrollin muodoista kyselyyn vastanneilla tutkijoilla on erittäin huolestuttavia kokemuksia. Sosiaalisen median aikakaudella "alhaalta ylöspäin" tuleva kontrolli eli yksityishenkilöiden aggressiiviset yritykset tutkijoiden vaientamiseksi ovat lisääntyneet.

Tutkimus antaa viitteitä myös siitä, että kyse ei ole vain yksittäisten kansalaisten äkkipikaisista reaktioista, vaan tietoisesti organisoidusta toiminnasta tutkijoiden vaientamiseksi. Erityisesti naistutkimus, rasismintutkimus, ympäristötutkimus ja energiapolitiikkaa sivuavat tutkimukset saavat aikaan vaientamisyrityksiä.

Kyselyyn osallistuneet tutkijat pitävät taloudellista ja poliittista ohjausta kuitenkin vakavimpana tieteen vapauteen puuttumisen muotona. Vapauteen puututaan useiden vaikutusmekanismien kautta: 1) tutkimusrahoituksen painopisteitä määritellään niin, että niiden avulla tutkimusta voidaan ohjata paremmin palvelemaan yritysten tuotekehityksen intressejä tai hallituksen ja ministeriöiden poliittisia tavoitteita, 2) tutkimuksen rahoittajat pyrkivät poistamaan tutkimustulosten raportoinnista epäsopivina pitämiään tuloksia, näkökulmia tai näkemyksiä, 3) tutkija sensuroi julkisessa keskustelussa itse omia kriittisiä kommenttejaan, jotta ei vaarantaisi asemaansa tai tulevia mahdollisuuksia.

\section{SUOMALAINEN ESIMERKKI VAIENTAMISESTA}

Tutkimustulosten kiistäminen, tuulesta temmattujen "vaihtoehtoisten faktojen" esittäminen tasavertaisina näkemyksinä tieteelliseen näyttöön perustuvien käsitysten kanssa, tutkijoiden uhkailu ja vainoaminen sekä suoranainen tiedevastaisuus ovat 2010-luvulla saaneet näkyvyyttä ja voimaa autoritaarisen populismin vahvistumisen myötä. Mutta ei "ylhäältä alas" suuntautuva rajoittaminen ole tuntematonta Suomessakaan.

Yksi esimerkki tutkijoiden vaientamiseen tähtäävästä poliittisesta ohjauksesta on Valtion teknillisen tutkimuskeskuksen (VTT) skandaali vuonna 2010. Laitoksen johto käytännössä määräsi, mitä tutkijat saivat julkisuudessa esittää ja argumentoida esimerkiksi turpeenkäytöstä, ydinvoimasta ja biopolttonesteistä. Tutkijoita kiellettiin niin kirjoittamasta Helsingin Sanomien mielipideosastolle kuin esiintymästä asiantuntijoina eduskunnan valiokuntien kuulemisissa.

Entinen VTT:n tutkija Janne I. Hukkinen selvittää tapausta artikkelissaan, joka paljastaa karmaisevalla tavalla tutkijan poliittisen painostuksen ja suun tukkimisen nyky-Suomessa. Eduskunnan oikeusasiamies antoi laitoksen johdolle huomautuksen tutkijoiden sananvapauden loukkaamisesta ja linjasi, että laitoksen tutkijoilla 
on perustuslaissa turvattu tieteen ja tutkimuksen vapaus. Hukkinen tähdentää, että tutkijan sananvapaus on otettava tiedepolitiikassa vakavasti esiin.

\section{YKSILÖT JA KÄYTÄNNÖT VAPAUDEN PUOLUSTAJINA}

Esa Väliverrosen luku tieteen vapauden ja tutkijoiden sananvapauden yhteiskunnallisesta merkityksestä avaa monipuolisesti tieteen vapauden problematiikkaa. Tieteen vapauden ytimessä on tiedeyhteisön autonomia suhteessa tutkimusaiheiden valintaan ja tutkimusten arviointiin. Artikkelissa käsitellään tieteen vapautta ja sen uhkia monelta kantilta. Väliverronen kannustaa akateemisia yhteisöjä omaksumaan aktiivisemman yhteiskunnallisen roolin vaiennettujen tutkijoiden ja tieteen julkisuuden puolustajina.

Samuli Reijula ja Petri Ylikoski tarkastelevat tieteellisen tiedon tuottamista ja tutkijan vapautta institutionaalisen tietoteorian kehyksessä. Tarkastelukulmana ovat institutionaaliset järjestelyt ja tutkimuksen sosiaaliset käytännöt, joiden varassa tieteellistä tietoa tuotetaan. Miten institutionaaliset olot olisi järkevintä järjestää, jotta tiedon tuotanto olisi sekä tehokasta että luotettavaa?

Reijulan ja Ylikosken varsin analyyttinen tarkastelu institutionaalisesta näkökulmasta nostaa esiin useita kiinnostavia ilmiöitä, muun muassa lääketieteen piirissä harjoitettavaa julkaisusuunnittelua sekä tutkijoiden välisen kilpailun vaikutusta niin kutsuttuun julkaisuvinoumaan.

\section{ENNALTA ARVAAMATON PERUSTUTKIMUS}

Kari Enqvist puolustaa artikkelissaan perustutkimusta, joka on itseohjautuvana usein päämäärätöntä. Juuri perustutkimuksen tuottamien tulosten periaatteellinen ennakoimattomuus on vapauden vahvin peruste. Asiastaan parhaiten perillä oleva tiedeyhteisö tiedostaa, mikä on tieteellisesti kiinnostavaa ja mitä kannattaa tutkia, muttei suinkaan voi etukäteen tietää, mitä tutkimus tulee löytäneeksi ja mihin tulokset johtavat.

Enqvist käsittelee tieteen vapautta ja ennakoimattomuutta esimerkkien - sähkön, paperin, internetin keksimisen - kautta. Vuoden 2010 yliopistolaki uusine johtamisjärjestelmineen ei lupaa hyvää itseohjautuvalle tieteelle. Enqvist varoittaa, että 2000-luvulla on merkkejä siitä, että "elinkeinoelämä haluaisi ulkoistaa omat tutkimustarpeensa yhteiskunnan maksettaviksi ja muuttaa yliopistot tuotekehitysosastoikseen" (s. 60). Välittömien taloudellisten hyötyjen tavoitteluun yhdistyy ymmärtämättömyys humanistisesta sivistysprojektista.
Samaan tapaan Juha Tuunainen, Reijo Miettinen ja Terhi Esko päätyvät snellmanilaista yliopistokäsitystä puolustaessaan näkemykseen, että tutkimuksen vaikuttavuuden seuraaminen indikaattoreiden avulla muodostuu osaksi poliittista kontrollia, joka on omiaan johtamaan yliopistojen ja valtionvallan välillä epäluottamuksen kulttuuriin.

Vapaa tutkimus ei ennalta tiedä, mitä löytää. Usein rahoittaja tietää etukäteen, mitä tuloksia haluaa tutkimuksen tuottavan.

\section{YLIOPISTOLAITOKSEN MUUTOS 2010-LUVULLA}

Uuden yliopistolain vaikutuksista tieteen vapauteen kirjoittavat yksityiskohtaisemmin Veera Kaleva ja Hanna Kuusela. Muutos on osa pidemmällä aikavälillä omaksuttua ajattelumallia, jossa yliopistot nähdään osana valtiollista innovaatiojärjestelmää. Innovaatiojärjestelmässä yliopistot palvelevat yhä vahvemmin kansallista kilpailukykyä, elinkeinoelämän tarpeita ja teknologian kehittämistä.

Tutkimuksen ja julkaisemisen vapaus, eli mitä tutkii ja missä julkaisee, on suhteellista oloissa, joissa niin yliopistot kuin yksittäiset tutkijatkin kilpailevat entistä kovemmin keskenään. Mitä kannattaa tutkia ja missä julkaista, kun haluaa kerätä meriittejä ja pelimerkkejä, ovat entistä tärkeämpiä 
valintoja. Kysymys näiden valintojen vapaudesta on myös kysymys tieteen vapaudesta.

Oili-Helena Ylijoki tarkastelee tutkijan asemaa ja tutkimuksen vapautta suhteessa siihen, millä markkinoilla tutkimusta tehdään. Akateemisten markkinoiden lisäksi hän erottelee yritysmarkkinat, politiikkamarkkinat, professiomarkkinat ja julkiset markkinat. Markkinat eroavat toisistaan muun muassa rahoituspohjan suhteen, ja kullakin markkinalla on erityinen toimintalogiikkansa. Tutkimuksen vapaus on kontekstisidonnaista ja suhteellista. Tutkijan identiteetin kannalta on olennaista, millä markkinoilla hän enimmäkseen toimii. Myös sitoutuminen tutkimuksen vapauden puolustamiseen kehkeytyy eri markkinoilla varsin erilaiseksi.

\section{ONKO TIETEEN VAPAUS LISÄÄNTYNYT?}

Kirjan historiallisesta osuudesta vastaa Hannu Riikonen kahdella artikkelillaan, joiden yhteinen pituus on noin 80 sivua. Ensimmäinen käsittelee tieteen vapautta ja riippumattomuutta aina antiikin ajoista 1800-luvulle. Pimeä keskiaikakaan ei ollut pelkkää pysähtyneisyyden aikaa, vaikka kirkolliset auktoriteetit pitkälti määrittelivätkin, mitä esimerkiksi yliopistoissa sai tutkia, opettaa ja lukea.

Esimerkiksi Turun akatemiassa tutkimuksen ei tullut 1600-luvulla esittää mitään uutta, koska totuudet löytyivät Raamatusta ja Aristoteles oli jo sanonut kaiken tähdellisen. Niihin ei voinut lisä- tä mitään uutta olematta väärässä. Riikosen mukaan on vaikea osoittaa, miten paljon tieteen vapaus on lisääntynyt tai vähentynyt, joskaan kirkon kaltaista auktoriteettia ankarine sanktiooikeuksineen ei enää ole olemassa. Läpi tieteen historian näkyy kaiken uuden vastustaminen. Syyt uuden vastustamiseen ovat olleet osittain ideologisia, osittain tieteen sisäiseen keskusteluun liittyviä. Ideologisesti on puolustettu vakiintuneita valta-asetelmia ja arvostuksia. Toisaalta uudet teoriat ja tulokset on testattu tiedeyhteisöjen piirissä.

Riikosen toinen artikkeli tarkastelee väitöskirjojen hylkäämisiä. Maailmalta tunnetuista hylkäämistapauksista Riikonen kuvaa Johann Wolfgang von Goethen, Walter Benjaminin ja Mihail Bahtinin väittely-yritykset. Oikeusmurhiksikin tulkittavat hylkäämiset ovat joskus johtaneet myös Suomessa traagisiin seurauksiin, mutta kaiken kaikkiaan Riikosen kirjaamista tapauksista on myös hauska lukea. Hylättyjen väittelijöiden joukossa on varsinaisia persoonallisuuksia.

Tapaukset ovat osaltaan osoitus tieteen vapauden rajoista, kun harhaoppisina tai liian arkaluontoisina pidetyistä aiheista tehtyjä tutkimuksia on hylätty. Taustalla ovat olleet myös paradigmakiistat sekä myös moraaliset, uskonnolliset ja poliittiset syyt. Ja tietenkin syynä on voinut olla myös se, että väitöskirja on ollut yksinkertaisesti niin huono, ettei sitä ole voinut hyväksyä. Tuorein hylkäämistapaus on vuodelta 2012.

\section{VAPAUS JA VIISAUS}

Kirja on moniaineksinen ja sisältää monia mielenkiintoisia tarkasteluja ja erittelyjä. Yliopistoihmiset ja tukijat löytävät siitä paljon kiinnostavaa analyysiä. Artikkelit ovat sinänsä hyviä ja laadukkaita, mutta kokonaisuutta vaivaa monista artikkelikokoelmista tuttu ongelma. Kirjan luettuaan jää kaipaamaan tieteen vapaudesta ja tutkijan sananvapaudesta systemaattista esitystä, jossa nyt esitellyt näkökulmat ja tarkastelut olisi saatettu järjestelmällisempään muotoon. Kirjan artikkeleita voi toki lukea yksitellen ja saada niistä runsaasti tietoa ja näkemystä ajatteluunsa.

Veera Kaleva ja Hanna Kuusela muotoilevat yhden ydinajatuksen kirjoittamalla, että hyvä tutkimus vaatii vapautta, ja tieteen vapaus edellyttää demokraattista johtamisjärjestelmää elinkeinoelämän tai poliitikkojen edunvalvonnan sijaan. Tämä ei täysin toteudu Suomen yliopistoissa. Yliopistoja ollaan kirjoittajien mukaan alistamassa "lyhytnäköisten intressien toimeenpanolaitoksiksi". "Kun tieteen tekeminen kääntyy innovaatiopöhinäksi [--], tiede menettää myös osan kyvystään kysyä monipuolisesti kiinnostavia kysymyksiä ja muuttaa maailmaa. Viisaiden ja kulloinkin tarpeellisten kysymysten kysyminen on taito, jonka osaavat parhaiten kunkin alan asiantuntijat." (s. 258.)

\section{HEIKKI SILVENNOINEN}

$\mathrm{VTT}$, professori

kasvatustieteiden laitos

Turun yliopisto 